\title{
A democracia brasileira em xeque (mate?): cinco interpretações
}

\author{
The brazilian democracy in check (mate?): five interpretations \\ La democracia brasileña en jaque (¿mate?): cinco interpretaciones
}

Recebido: 26/11/2021 | Revisado: 01/12/2021 | Aceito: 02/12/2021 | Publicado: 12/12/2021

\author{
Leon Karlos Ferreira Nunes \\ ORCID: https://orcid.org/0000-0001-5423-7482 \\ Universidade Federal do Rio Grande do Norte, Brasil \\ E-mail: leonknunes@yahoo.com.br \\ Angelo Girotto Neto \\ ORCID: https://orcid.org/0000-0001-8794-0799 \\ Universidade Federal do Rio Grande do Norte, Brasil \\ E-mail: angelogirotto@gmail.com
}

\begin{abstract}
Resumo
Após um gradual desenvolvimento desde sua emergência nos anos 1980, a democracia no Brasil chegou a dar sinais de ter alcançado certa consolidação. No entanto, conflitos e desequilíbrios entre os poderes da República, articulações de teor conspiratório, retorno dos militares a cargos estratégicos do Executivo, e um processo de impeachment amparado por uma frágil acusação de crime de responsabilidade em que o dolo não ficou constatado, entre outros fenômenos, geraram instabilidade e recolocaram a discussão sobre a questão democrática em evidência. Neste artigo, nosso intuito é traçar uma revisão bibliográfica sobre a temática mencionada, discutindo os problemas e limitações da democracia brasileira pós-ditadura militar a partir de cinco interpretações: Carlos Nelson Coutinho (1979), Boaventura de Souza Santos e Leonardo Avritzer (2002), Wanderley Guilherme dos Santos (2017), Luís Felipe Miguel (2017) e Vladimir Safatle, (2017). Como objetivos específicos, pretendemos apreender uma perspectiva sobre o conceito de democracia, sempre que possível observando as peculiaridades brasileiras; identificar, a partir dessas leituras, os problemas recentes da política nacional; e, por fim, traçar um panorama dos impasses da democracia em nosso país, isto é, o que a faz estar sempre sobre o fio da navalha.
\end{abstract}

Palavras-chave: Democracia brasileira; Política brasileira; Participação política.

\begin{abstract}
After a gradual development since its emergence in the 1980s, the democracy in Brazil has even shown signs of achieving certain consolidation. However, conflicts and imbalances between the powers of the Republic, conspiracy articulations, the return of the military to strategic positions in the Executive, and an impeachment process supported by a fragile accusation of a crime of responsibility in which the fraud was not found, among others phenomena, generated instability and put the discussion on the democratic issue in evidence. In this article, our aim is to outline a bibliographic review on the aforementioned theme, discussing the problems and limitations of post-military dictatorship Brazilian democracy based on five interpretations: Carlos Nelson Coutinho (1979), Boaventura de Souza Santos and Leonardo Avritzer (2002), Wanderley Guilherme dos Santos (2017), Luís Felipe Miguel (2017) and Vladimir Safatle, (2017). As specific objectives, we intend to apprehend a perspective on the concept of democracy, whenever possible, observing the Brazilian peculiarities; identify, from these readings, the recent problems of national policy; and, finally, to draw a panorama of the impasses of democracy in our country, that is, what makes it always on the razor's edge.
\end{abstract}

Keywords: Brazilian democracy; Brazilian politics; Political participation.

\section{Resumen}

Después de un desarrollo gradual desde su surgimiento en la década de 1980, la democracia en Brasil incluso ha mostrado signos de lograr cierta consolidación. Sin embargo, conflictos y desequilibrios entre los poderes de la República, articulaciones de carácter conspirativo, el regreso de los militares a posiciones estratégicas del Ejecutivo, y un proceso de acusación sustentado en una débil acusación de un delito de responsabilidad en el que el fraude no fue encontrado, entre otros fenómenos, generaron inestabilidad y pusieron en evidencia la discusión sobre el tema democrático. En este artículo, nuestro objetivo es esbozar una revisión bibliográfica sobre el tema antes mencionado, discutiendo los problemas y limitaciones de la democracia brasileña post dictadura militar a partir de cinco interpretaciones: Carlos Nelson Coutinho (1979), Boaventura de Souza Santos y Leonardo Avritzer (2002), Wanderley Guilherme dos Santos (2017), Luís Felipe Miguel (2017) y Vladimir Safatle, (2017). Como objetivos específicos, pretendemos aprehender una perspectiva sobre el concepto de democracia, siempre que sea posible, observando las peculiaridades brasileñas; identificar, a partir de estas lecturas, los problemas recientes de la política nacional; y, 
finalmente, trazar un panorama de los impases de la democracia en nuestro país, es decir, lo que la hace estar siempre al filo de la navaja.

Palabras clave: Democracia brasileña; Política brasileña; Participación política.

\section{Introdução}

Sendo um esporte amador muito popular no Brasil — frequentemente tratado como passatempo e carregando estigma que teve e ainda tem como um jogo ligado à malandragem —, a sinuca está presente em muitos bares e clubes, e consiste numa das tantas modalidades possíveis de jogos de bilhar. Sem se ater aos detalhes, e considerando que não há uma regra oficial, a partida convencionalmente consiste em encaçapar a chamada bola da vez, de variadas cores, sempre a partir da bola branca com a qual um jogador habilidoso pode controlar todo o jogo. Acontece que às vezes a disposição das bolas encontra um limite embaraçoso: a bola branca termina se alocando no canto da mesa, numa posição que, na prática, a impede de alcançar a desejada bola da vez, senão com uma jogada de muito efeito. O impasse, então, está dado. Essa situação é conhecida como "sinuca de bico". E não é raro que a partida termine nesse momento.

Essa breve descrição parece uma analogia da democracia brasileira. Após um gradual desenvolvimento desde sua emergência nos anos 1980, ela em alguns momentos sinalizou a ideia de que havia alcançado certa consolidação. Mudanças na legislação eleitoral, processos de impeachment, pequenos golpes caminhavam junto a um certo grau de estabilidade crescente nos primeiros vinte e cinco anos de redemocratização, especialmente com as principais regras eleitorais sendo respeitadas, isto é, com mandatos eleitos sucedendo-se conforme determina o regulamento. Mas como nada é definitivo na História, a verdade é que ela caminhou sempre no fio da navalha.

O respeito às regras do jogo, após certo momento difícil de delimitar, já não parece garantir a preservação da democracia. Conflitos e desequilíbrios entre os Poderes da República, articulações de teor conspiratório, retorno dos militares a cargos estratégicos do Executivo, e um processo de impeachment amparado por uma frágil acusação de crime de responsabilidade em que o dolo não ficou constatado; tudo isso, junto a outros fenômenos, gerou a incômoda sensação de que talvez a democracia não caminhasse tão bem. A ascensão de figuras políticas por um discurso populista de direita (não raro flertando com extremismos e sinalizando desprezo para com a institucionalidade) completam o pacote: a democracia brasileira chegou numa sinuca de bico. O jogo político está travado, de modo que ninguém sabe bem como será o futuro. Desse impasse, é muito difícil se livrar. No xadrez — aproveitando uma outra analogia —, diríamos que a democracia brasileira entrou em xeque. Mas será que o xeque é mate? Isso é o que discutiremos adiante.

Diga-se de passagem, todo regime democrático passou por processos afins. Instabilidades, crises, retrocessos, rupturas da ordem... Esses fenômenos são próprios da vida política, e a democracia, se oferece contrapesos para limitar os poderes dos que eventualmente estão situados nos postos mais importantes, também é frágil na resistência a atividades conspiratórias e/ou extralegais que ponham em risco o seu ordenamento. Essa resistência vai depender muito mais das tradições nacionais do que propriamente dos mecanismos formais desse regime político para sua autopreservação. No caso do Brasil, cabe dizer, essa tradição é problemática.

Assim, nosso intuito é discutir os problemas e limitações da democracia brasileira pós-ditadura militar a partir de cinco interpretações, não necessariamente seguindo o mesmo enfoque, no entanto todas versando sobre a questão democrática: referimo-nos a Carlos Nelson Coutinho (1979), Boaventura de Souza Santos e Leonardo Avritzer (2002), Wanderley Guilherme dos Santos (2017), Luís Felipe Miguel (2017) e Vladimir Safatle, (2017).

\section{Metodologia}

Nosso estudo se ampara aqui numa pesquisa qualitativa, dentro dos termos colocados por Minayo (1993), com quem 
concordamos ao enfatizar que o objeto das Ciências Sociais é essencialmente qualitativo, de modo que os códigos das ciências que, pela própria natureza, precisam ser recortados, são incapaz de contê-la em si. Daí decorre nossa opção metodológica.

Desse modo, pretendemos, por meio de uma revisão bibliográfica, priorizando os autores apresentados na seção anterior, apreender uma perspectiva sobre o conceito de democracia, sempre que possível observando as peculiaridades brasileiras. É daí que identificaremos os problemas recentes da política nacional e, por fim, traçaremos um panorama dos impasses da democracia em nosso país, isto é, o que a faz estar novamente sobre o fio da navalha.

\section{Resultados e Discussão}

\subsection{O Brasil Redemocratizado}

A posse de José Sarney, vice-presidente eleito sob voto indireto porém ascendendo à condição de titular após o adoecimento e consequente falecimento de Tancredo Neves, é de modo geral tido como o ponto de partida da redemocratização brasileira. Naquela segunda metade da década de 1980, uma nova Constituição seria promulgada, os partidos políticos cassados vinte anos antes seriam regularizados e as últimas obras censuradas no período da ditadura militar seriam liberadas.

Com o constante crescimento das organizações políticas populares e movimentos sociais, as bases para um Brasil democrático estavam dadas. Em outros termos, temos que "Com a aprovação do novo marco jurídico-legal, pode-se dizer que estava completada a obra da transição. Esta não se fizera, contudo, sem duros percalços”, conforme assinala Spinelli (2014), acrescentando a posição dos militares como os principais impositores desses percalços, com suas intervenções no processo político e no processo constituinte. Além disso, as condições do capitalismo dependente-associado do país foram um dos entraves para que o Brasil tivesse avanços em resolver persistentes problemas históricos.

Essa herança fará com que a democracia brasileira, ainda que sob um Estado de Direito, caminhe junto com reações sociais e com uma cultura política com fortes doses de autoritarismo. Tal fenômeno não arrefeceu mesmo com a ascensão de governos neoliberais nos anos 1990, que, se desestatizavam parte relevante do parque industrial brasileiro, ainda assim o faziam a partir de procedimentos verticais, com recurso excessivo à edição de medidas provisórias, o que põe em questão a concepção clássica de tripartição de poderes. Deve-se convir, porém, que essa tal tripartição é, no seu fundamento, algo meramente formal. Diz Poulantzas (2019, pp. 311-312) que, "a despeito da declaração de separação dos poderes, (...) podemos constatar que o Estado funciona como unidade centralizada, organizada a partir da dominância de um desses poderes sobre os outros”.

A eleição de Fernando Collor como sucessor de Sarney marcou o resgate do discurso populista ao centro da política brasileira. Dizendo-se "o caçador de marajás", o novo presidente foi eleito com grande apoio midiático e fazendo de si um personagem jovem e outsider. Seu governo, contudo, ficou marcado pelo fracasso do Plano Collor, o que deu contexto para que denúncias de corrupção posteriores levassem-no ao impeachment. Vale destacar que, apesar do sucesso eleitoral desse presidente, seu governo ainda vivia, assim como o anterior, os ecos do que Maciel (2012) considera uma crise de hegemonia. Enquanto no contexto da ditadura militar, as frações hegemônicas conseguiram unificar outras frações no bloco de poder, nos primeiros governos da era democrática isso ficou mais difícil, o que explicaria a queda sem maiores resistências de Collor.

Itamar Franco foi seu sucessor, tendo como grande destaque durante a sua gestão a contenção da inflação sem o uso de procedimentos como o congelamento de preços e os confiscos, além do Plano Real, que instituiu uma nova moeda, tornando-se um momento paradigmático na história econômica do Brasil. Esse plano, acrescentado de algumas medidas como a Lei de Responsabilidade Fiscal e o chamado tripé macroeconômico (um conjunto de medidas que incluíam o câmbio flutuante e os regimes de meta de inflação e de superávit), ditaria o tom e as limitações da política brasileira. O governo de Fernando Henrique Cardoso (FHC) intensificou o processo de privatização como passo fundamental para a modernização dos serviços públicos, conseguindo manter a estabilidade da moeda, porém levando o país a um endividamento crescente. O resultado seria uma crise econômica que se intensificaria em seu segundo mandato, com o governo se encerrando bastante mal avaliado, abrindo as 
possibilidades para a ascensão de um governo de oposição.

A oposição, representada por Lula e pelo Partido dos Trabalhadores (PT), no entanto, embora tenha aplicado medidas fundamentais como programas sociais que levaram a uma inédita redução da fome no país, o crescimento dos investimentos na área social (podemos citar como exemplo a educação, que teve um orçamento continuamente crescente entre 2003 e 2014) e um reordenamento da política externa brasileira, sob novas bases soberanas (e inclusive tornando a China seu maior parceiro econômico), não alterou a política econômica nacional. Assim, a linha de manutenção da estabilidade da moeda se mantinha como o centro da estratégia econômica nacional, sendo o principal fator de conflito do governo Lula com sua base.

Dilma Rousseff, sucessora de Lula, chegou a sinalizar uma desobediência a essas premissas, porém o quadro de crise global e de fim do ciclo de commodities enfraqueceu-a politicamente, ainda que tenha alcançado a reeleição em 2014. Procurando, por meio de um duro ajuste fiscal, sanar a agressividade de opositores ligados ao mercado, ela só elevou sua impopularidade após uma crise recessiva que se estende até hoje, oferecendo as condições políticas para um processo de impedimento que tinha uma precária razão jurídica, em abril de 2016. Ribeiro (2019) diz que o Brasil retrocedeu cinquenta anos em três. Não seria forçado dizer que, até o momento, continuamos retrocedendo algumas décadas mais...

Nas próximas páginas, estudaremos a democracia tanto a partir de perspectivas teóricas como de avaliações empíricas, de modo a absorvermos uma noção um pouco mais aprofundada sobre as características de nossa política, situando-nos entre seus potenciais e seus limites. Os trabalhos analisados são recentes, com reconhecimento tal que já os situa como obras de referência no debate contemporâneo.

\subsection{Coutinho e o "valor universal"}

Quando escreveu A Democracia como Valor Universal, em 1979, Carlos Nelson Coutinho estava entre os que buscavam alternativas de releitura das teses marxistas a partir de um prisma não-soviético. A intenção era pensar vias de transição do capitalismo ao socialismo que fossem alternativas à tradicional via da luta armada.

Coutinho discute os temas de seu tempo. Ainda no princípio de seu texto, resgata uma fala de Enrico Berlinguer, um dos mais proeminentes marxistas europeus, dirigente do Partido Comunista Italiano (PCI), asseverando a democracia como um valor historicamente universal. O PCI era talvez a maior expressão do que se convencionou chamar na ocasião de eurocomunismo, isto é, uma linha tática dos partidos comunistas da Europa Ocidental que preconizavam uma transição ao socialismo por dentro das vias democráticas.

A originalidade de Coutinho consistiu no seu esforço de trazer essa discussão para o Brasil, num momento em que o regime autoritário estava arrefecendo, e já se lançando ao embate, com firme questionamento às teses que imputavam à democracia a condição de recurso meramente instrumental de dominação da burguesia.

Essa visão estreita se baseia, antes de mais nada, numa errada concepção da teoria marxista do Estado, numa falsa e mecânica identificação entre democracia política e dominação burguesa. Mas implica, em segundo lugar, ainda que por vezes implicitamente, uma concepção equivocada das tarefas que se colocam atualmente ao conjunto das forças populares brasileiras: essas tarefas não podem ser identificadas com a luta imediata pelo socialismo, mas sim com um combate árduo e provavelmente longo pela criação dos pressupostos [grifo do autor] políticos, econômicos e ideológicos que tomarão possível o estabelecimento e a consolidação do socialismo em nosso País. (Coutinho, 1979, pp. 34-35)

Nesse trecho, Coutinho parece se antecipar a uma crítica que até hoje se dirige a seu artigo, e que momentos de instabilidade como o atual são levantados como provas de seu equívoco; quando ele afirma que a criação dos pressupostos que tornarão possível o estabelecimento do socialismo advirão de um "combate árduo e provavelmente longo", sem, naturalmente, arriscar um tempo, ele já deixa claro que não é qualquer democracia que se caracteriza como terreno apto à afirmação das forças 
populares. Poderíamos inferir, assim, que o golpe jurídico-parlamentar de 2016, ainda que fragilize a democracia, não significa uma negação da tese coutiniana, mas sim transpareça no conjunto de sua reflexão teórica como um terreno em que se empreende o "combate árduo" que ele preconizava. E, nesse combate em particular, as forças populares foram derrotadas.

O esforço desse estudioso é muito perceptível nas suas tentativas de pôr em questão os sentidos excessivamente literais que as concepções marxistas costumam ter. Um exemplo é a ideia de que a máquina estatal deve ser destruída para que se possa implantar uma nova sociedade, que ele vai procurar traduzir indicando se tratar de uma transição de institutos políticos vigentes para outros, novos, hoje inexistentes (ou existentes apenas embrionariamente), e não necessariamente uma ruptura forçada, violenta, imediata, de um regime para outro. Esses destaques vêm sempre acompanhados da ressalva de que a democracia socialista não pode, entretanto, ser vista como mera continuação da democracia liberal.

Entre os institutos que o autor elenca como embrionários, elementos da nova democracia já emergentes por influência do desenvolvimento das forças produtivas, estão os sindicatos, partidos, associações profissionais, comitês de empresa e de bairro, etc. O enfoque fundamental de Coutinho, como um marxista clássico, ainda era o da classe operária, e por meio desses institutos essa classe se organizaria de baixo para cima, constituindo-se como sujeitos políticos ativos.

Não seria difícil mostrar como a formação desses sujeitos políticos coletivos — não previstos pela atomista teoria liberal clássica - corresponde aos processos de socialização da produção que se acentuam no capitalismo e, em particular, no capitalismo monopolista de Estado. Portanto, é a própria reprodução capitalista enquanto fenômeno social global que impõe essa crescente socialização da política, ou seja, a ampliação do número de pessoas e de grupos empenhados politicamente na defesa dos seus interesses específicos. A essa socialização objetiva da participação política deve corresponder, em medida cada vez maior, uma socialização dos meios e dos processos de governar o conjunto da vida social. (Coutinho, 1979, pp. 37-38)

A partir daí já se pode inferir o que esse autor pensa como sendo as grandes vias de transição. Elas passam pela noção de representatividade. É ampliando-a que os organismos populares de democracia direta e indireta assumem o caráter de síntese política dos sujeitos políticos coletivos.

Uma pergunta que emerge seria: é Marx o referencial dessa linha tática? Coutinho assevera que sim, destacando que o roteiro para isso consiste na articulação entre as formas de representação tradicionais e os organismos de democracia direta, que, ao promover a mencionada síntese política, alcança a hegemonia dos trabalhadores sobre o governo da sociedade como um todo. Aqui, Coutinho se aproxima não somente de Marx e de Engels, mas também do italiano Antonio Gramsci, do qual viria a ser uma das maiores autoridades no Brasil. Coutinho lembra que alcançar a hegemonia sobre o governo significa criar os meios para a apropriação social da política, o que permitiria levar (a longo prazo, deva-se dizer) à extinção do Estado.

É nesse sentido que cabe entender a lúcida observação de Gramsci, segundo a qual a "sociedade regulada" (sem classes) é aquela na qual o Estado será absorvido pelos organismos autogeridos da "sociedade civil". Podemos concluir esse rápido esboço afirmando que a relação da democracia socialista com a democracia liberal é uma relação de superação dialética (Aufhebung): a primeira elimina, conserva e eleva a nível superior [grifos do autor] as conquistas da segunda. (Coutinho, 1979, p. 40)

Tendo fundamentado uma noção de democracia como via possível de transição ao socialismo, Coutinho passa a analisar o quadro brasileiro, partindo de um acertado panorama de como se deram as transformações políticas e a modernização econômico-social no Brasil, isto é, a partir do que se convencionou chamar de "via prussiana", a qual poderíamos resumir na ideia de conciliação entre frações das classes dominantes e na aplicação de políticas verticais conservando as relações de produção atrasadas (e aqui ele destaca o latifúndio) e a reprodução ampliada da dependência ao capitalismo internacional.

Feito esse panorama, a tarefa que se coloca para o povo brasileiro seria de amplo alcance, consistindo numa luta "para 
inverter essa tendência elitista ou 'prussiana' da política brasileira e para eliminar suas consequências nas várias esferas do ser social brasileiro" (Coutinho, 1979, p. 41), residindo essa tarefa em uma profunda renovação democrática do conjunto da vida brasileira. Nesse sentido, as conquistas da democracia liberal são fundamentais, porque se tratam de um regime de liberdades formais que torna possível a superação da modalidade da "via prussiana" e ao mesmo tempo é um pressuposto que deverá ser reposto - isto é, deverá ser conservado e ao mesmo tempo aprofundado —, criando um patamar mínimo, uma base inicial a partir da qual a luta pelo socialismo pode avançar.

Por fim, é bom destacar que para esse autor os ensinamentos gramscianos aparecem sempre com destaque. Não à toa ele destaca que a luta pela renovação democrática percorre a lógica da "guerra de posição" como método, afastando tentações golpistas ou militaristas. Isso, segundo Coutinho (2012, p. 45), "implica em conceber a unidade como valor estratégico". Ele encerra elencando dois planos principais para o que chamou de renovação democrática:

Em primeiro lugar, lógica e cronologicamente trata-se de primeiro conquistar e depois consolidar um regime de liberdades fundamentais, para o que se toma necessária uma unidade com todas as forças interessadas nessa conquista e na permanência das regras do jogo a serem implantadas por uma Assembléia Constituinte dotada de legitimidade.

E, em segundo, trata-se de construir as alianças necessárias para aprofundar a democracia no sentido de uma democracia organizada de massas, com crescente participação popular; e a busca da unidade, nesse nível, terá como meta a conquista do consenso necessário para empreender medidas de caráter antimonopolista e antiimperialista e, numa etapa posterior, para a construção em nosso País de uma sociedade socialista fundada na democracia política. (Coutinho, 1979, p. 45)

Como se vê, no xadrez da luta democrática brasileira, o primeiro plano de Coutinho parece ter sido executado com êxito ainda nos anos 1980. Porém, o segundo - ainda que tenhamos visto emergir uma democracia popular efervescente no país após a virada do século - não conseguiu, contudo, assumir um caráter antimonopolista. Como no xadrez, nem sempre estar na dianteira durante boa parte do jogo significa alcançar a vitória no final.

\subsection{Boaventura de Sousa Santos e Leonardo Avritzer: o cânone democrático}

Quando Boaventura de Souza Santos e Leonardo Avritzer (2002) empreenderam suas reflexões sobre os caminhos para a democracia, o mundo ainda estava sob a égide neoliberal. Alguns acontecimentos emblemáticos sinalizavam um desgaste, como a grande manifestação de Seattle em 1999 e o Fórum Social Mundial em 2001, no entanto a hegemonia econômica e política dos neoclássicos ainda parecia sólida. Naquele momento, muito se preconizava a democracia como via política consolidada. Porém, para além de um regime formal, ela parecia não se preencher de nada mais do que isso: mera formalidade.

Foi daí que os dois autores iniciaram suas reflexões. Resgatando Amartya Sen e Immanuel Wallerstein, já começam pensando a democracia em duas frentes: primeiro como uma conquista; segundo como um slogan vazio de conteúdo. Após um apanhado acerca do debate sobre a democracia ao longo do Século XX — que eles constatam como limitados —, o esforço de ambos começa com a proposta de traçar um itinerário contra-hegemônico para o referido debate.

De uma discussão marcadamente disputada por interesses políticos, Santos e Avritzer vão observar que no Século XX, a teoria democrática hegemônica procurará afirmar a democracia como forma, e não como substância, sendo Hans Kelsen o formulador principal dessa hipótese. Essa noção procedimentalista vai ser transformada em uma forma de elitismo democrático a partir do trabalho de Joseph Schumpeter (2017) e Norberto Bobbio (1979), uma vez que em suas visões a soberania popular não aparecia como possibilidade racional para a constituição de um governo.

Bobbio vai além, sendo aquele que sintetiza a mudança de perspectiva em relação à desconfiança de Max Weber com o aumento da capacidade de controle da burocracia sobre o indivíduo moderno, destacando que o cidadão, ao optar pela sociedade de consumo de massa, sabe que está abrindo mão do controle sobre as atividades políticas e econômicas em favor de burocracias privadas e públicas. Em tese, fica uma coisa pela outra. Mas Santos e Avritzer observam que há algo que os teóricos acima não 
atentam: as limitações criativas da burocracia e sua consequente dificuldade de absorver o conjunto das informações envolvidas na gestão pública.

As formas burocráticas descritas por Weber e Bobbio são monocráticas na forma como gerem o pessoal administrativo e na forma como advogam uma solução homogeneizante para cada problema enfrentado em cada jurisdição. Ou seja, a concepção tradicional de gestão burocrática advoga uma solução homogênea para cada problema, a cada nível da gestão administrativa, interior de uma jurisdição administrativa. No entanto, os problemas administrativos exigem cada vez mais soluções plurais nas quais a coordenação de grupos distintos e soluções diferentes ocorrem no interior de uma mesma jurisdição. (Santos \& Avritzer, 2002, p. 48)

A sentença acima demonstra como as burocracias centralizadas são frágeis para agregar ou lidar com as demandas complexas que exigem a elaboração de políticas sociais, ambientais, culturais, etc. Daí adviriam os chamados “arranjos participativos", para suprimir essa limitação.

Outro elemento importante a fazer parte da concepção hegemônica de democracia é a percepção de como a representatividade, especialmente em países de grande escala como o nosso, é fundamental para o problema da "autorização", isto é, da legitimidade do poder constituído, sendo de Robert Dahl (2001) que eles extraem esse ponto.

A seguir, os autores passam a pensar nas concepções contra-hegemônicas, frisando que, nesse caso, o problema está "estreitamente ligado ao reconhecimento de que a democracia não constitui um mero acidente ou uma simples obra de engenharia institucional". A maneira correta de pensá-la seria "perceber que a democracia é uma forma sócio-histórica e que tais formas não são determinadas por quaisquer tipos de leis naturais" (Santos \& Avritzer, 2002, p. 51). O procedimentalismo não é negado nesse caso. Ambos vão lembrar que é Jurgen Habermas (1996) o responsável por pensar o procedimentalismo como prática social e não como método de constituição de governos, ampliando a dimensão social do conceito. E mais à frente, também os movimentos sociais serão inseridos na reflexão, com papel relevante na institucionalização da diversidade cultural.

Quando passam a se debruçar mais intensamente sobre casos, os autores chegam, entre outros exemplos, à análise da realidade brasileira, na qual observam que os potenciais da democracia participativa são mais claros que em outros lugares. Essa conclusão inicial vem da leitura do texto constitucional de 1988, que incorporou novos elementos culturais, reforçou a iniciativa popular e ampliou os mecanismos de participação.

É curioso notar que quando examinam o exemplo brasileiro, Santos e Avritzer não tomam como referência o governo central, mas sim as experiências regionais de Porto Alegre, em especial, e, eventualmente, de Belo Horizonte. Nos dois casos, dirigidos por partidos de centro-esquerda (Partido dos Trabalhadores e Partido Socialista Brasileiro, respectivamente), iniciativas democráticas eram encampadas. O principal exemplo era o orçamento participativo $(\mathrm{OP})$, o principal instrumento na análise a mostrar o potencial de ampliação da democracia participativa. Um ponto curioso dessa medida consistia no seu caráter nãopartidário, conforme podemos ler no trecho a seguir:

Em primeiro lugar, apesar da importância do Partido dos Trabalhadores na experiência do orçamento participativo, existe um controle reduzido do processo por parte do PT, com uma baixa filiação partidária dos participantes da OP. [...] o OP em Porto Alegre e em Belo Horizonte descentraliza e democratiza apenas o processo de deliberação, mantendo nas mãos da prefeitura o processo de implementação administrativa das decisões. Nesse caso, ele incentiva o controle da administração pública pelo Conselho do OP em Porto Alegre e pelo Comforças em Belo Horizonte (AVRITZER, 2002), criando, assim, um mecanismo de controle da administração relativamente invulnerável a processos de corrupção, dado ao excesso de mecanismos públicos e formas de controle. (Santos \& Avritzer, 2002, p. 70)

Apesar da empolgação dos autores no estudo desse caso, o fato é que essa política, ainda que tenha se expandido no Brasil, não alterou o caráter marginal das práticas participativas na cultura política nacional. É Costa (2010) que, analisando um conjunto de municípios dentre os mais importantes a aplicarem o orçamento participativo, vai perceber que eles não conseguiram 
sequer atingir a fase de efetividade. "Mesmo naquelas historicamente conhecidas e exemplos mundiais, como Porto Alegre e Belo Horizonte, ainda têm muito a percorrer até serem totalmente institucionalizadas” (Costa, 2010, p. 27).

\subsection{O impedimento da democracia em Wanderley Guilherme dos Santos}

Quando publica A Democracia Impedida, em 2017, Wanderley Guilherme dos Santos, decano da ciência política brasileira, está empreendendo um esforço de identificar o que talvez sejam — e ele defende que são — os marcos iniciais para o desordenamento de nossa democracia nos dias de hoje. É na Ação Penal 470, mais conhecida como julgamento do Mensalão, que ele percebe a inauguração da atitude conservadora de interromper por via não eleitoral a liderança política instituída, no caso a do Partido dos Trabalhadores. O exame de Santos do caso, como costuma ser, será rigoroso, e não à toa seu livro, tão logo publicado, já se configurou como de leitura obrigatória para os estudiosos da vida política brasileira.

Santos não nega o caráter corriqueiro dos golpes na vida política, não somente no Brasil, mas mundo afora, ainda que situe o caráter militar do golpe clássico. Com o tempo, ele percebe, as coisas mudaram. E aí, a problemática da democracia deve passar a ser estudada não somente a partir da dinâmica da conspiração, mas também à investigação da dinâmica institucional de esvaziamento da vontade eleitoral. E é a partir desse momento que ele vai situar o ineditismo dos golpes parlamentares, elencando o fato de que neles:

[...] a ruptura tenta preservar o efeito-legalidade das instituições, a normalidade rotineira das operações, enquanto altera a hierarquia das preferências governamentais, substituindo o luzeiro teleológico, a finalidade que, alegadamente, preside as decisões subversivas. Distinguem-se dos protocolados golpes militares por não amputarem as prerrogativas funcionais das instituições. Dispensando o aparato militar, não se identificam, contudo, com as habituais soluções civis para crises de grande envergadura, estas bem catalogadas pelas análises acadêmicas — por exemplo, a substituição do regime presidencialista pelo parlamentarista ou vice-versa. Quanto às consequências, portanto, nem ditaduras abertas nem substituição imprevista de regimes de governo resultam necessariamente de golpes parlamentares. Na alternativa ditatorial, o Parlamento desaparece ou converte-se em mísera ficção com tarefas propagandísticas; em golpes "civis", busca-se a redenção da conspirata pela troca na mecânica de governo quando se trata, cruamente, de substituição dos ocupantes e da ideologia do poder. (Santos, 2017, p. 12-13. )

Nesse trecho, Santos resume de forma luminosa o mecanismo do golpe parlamentar, fenômeno que em seguida situa como genuinamente inédito na história das democracias representativas. Além do impeachment de Dilma Rousseff, ele ainda especula como de raiz igualmente parlamentar o assalto ao poder no Paraguai (2012), além de também resgatar o golpe hondurenho (2009) como acontecimento semelhante, amparado pela sentença do Tribunal Internacional da Democracia, que caracterizou os três episódios como golpes de Estado.

Reforçando o caráter inédito da investigação, ainda assim Santos faz questão de relembrar as lições de clássicos da sociologia política, como $O$ Federalista aqui ou A Democracia na América de Alexis de Tocqueville ali, listando as especificidades de cada um e suas limitações na tentativa de dar respostas aos dilemas do presente. A partir desse ponto, ele se dedica ao que interessa, isto é, o golpe parlamentar e suas particularidades, começando com a diferença de que o golpe militar, se bem-sucedido, imediatamente desaloja opositores de posições de poder — fazendo inclusive uso de repressão, se necessário —, enquanto no seu correspondente parlamentar, os ritos institucionais permanecem em vigor, ainda que se aplique um roteiro intenso de proposições de leis voltadas à subversão política, econômica e social da ordem destituída. Em outras palavras: o Parlamento (e a nova coalizão governista) passa a atuar incansavelmente no rumo de desmantelar as políticas sociais e econômicas aplicadas pelo governo ora derrubado.

Estes golpes, no entanto, não costumam resultar em processos estáveis. Pelo contrário, a instabilidade que levou à derrocada dos golpeados não desaparece. Isso porque "o acordo prévio sobre quem deve deixar o governo não antecipa quem deve herdá-lo, e ainda menos como exercê-lo" (Santos, 2017, p. 17). Daí decorre que o bloco golpista, se antes uma unanimidade, 
já de imediato manifesta o esboço das divergências até ali ocultas. Não foi à toa que o fim do governo biônico de Michel Temer foi marcado por uma eleição com mais de dez candidatos a presidente, nenhum dos quais se afirmando claramente como situação.

Em comum com 1964, Santos vai dizer que o golpe de 2016 expressa claramente a reação dos conservadores à participação popular na vida pública e rejeição ativa de políticas de acentuado conteúdo social. Santos também supõe, de forma sensata, que "com o tempo" os setores iludidos se somarão à oposição automaticamente constituída depois do golpe. Bem, se a oposição não assumiu linha comum, o fato é que pouca gente se afirmou como situação nos anos seguintes ao impeachment.

O detalhe da retórica anticorrupção também recebe um olhar do autor. Mais do que o problema em si, diga-se de passagem, ele destaca como mais importante observar o "estilo leviano dos denunciadores contumazes", adicionando a isso o discurso oco presente nessa cantilena moralista, com direito a suas características ironias: "Última moda no léxico político, 'ética' disputa com 'republicano' a primazia de não significar coisa alguma no cotidiano" (Santos, 2017, p. 40). Além disso, de modo geral, o mantra anticorrupção quase sempre oculta um discurso antipopular. "Em crises com denúncia de corrupção e apelos de governos éticos, na maioria absoluta das vezes, o governo denunciado é de inclinação popular". O exemplo maior disso reside na linha tomada pelos próprios governos que se instalam após a destituição dos anteriores por acusações dessa natureza: "as prioridades de governos usurpadores não têm sido o combate à corrupção, mas, isso sim, notável, a adoção de medidas estancando políticas favoráveis aos destituídos", sentencia Santos (2017, p. 42).

No que se refere ao caso concreto do governo Dilma Rousseff, a instabilidade se intensificou após as eleições de 2014. Derrotado, o Partido da Social Democracia Brasileira de Aécio Neves decidiu percorrer o caminho histórico dos antigos golpistas: primeiro, a acusação de fraude eleitoral; depois, as acusações de corrupção. Foi assim em 1950, em 1955, em 1964 e em 2016. "Quando a esquerda despertou, diante da adoção da derrotada agenda direitista, era tarde”, diz Santos, lembrando quão prejudicial foi para Dilma Rousseff o ajuste fiscal aplicado logo após a confirmação da sua reeleição.

A fase final do assalto parlamentar na Câmara dos Deputados, com a votação realizada em 17 de abril de 2016, foi, por aclamação unânime dos observadores, grotesca. A tese do impedimento presidencial, se perfilhada integralmente por alguns, como de justiça, revelou-se para todos e afinal foi explicitamente defendida como uma punição política para a qual os argumentos constitucionais só acrescentam certo impudor. (Santos, 2017, p. 46)

Por grotesco que seja, não surpreende, na verdade, que o Brasil tenha assumido esse destino. Isso porque, após análise de fôlego acerca da democracia e do contexto global em que se inseria o Brasil, "a ecologia das instituições nacionais pós-1988 era favorável tanto ao exercício da democracia quanto, o que the vai associado, o surgimento da conjectura da insatisfação democrática e ao possível desenlace desfavorável à fração popular do país”, conforme lembra o próprio Santos (2017, p. 157).

É a partir daí que ele irá pensar na AP 470 como catalisadora da instabilidade vigente no país, sendo o meio de estreia do que ele chama de "ostensivo espetáculo de intervenção jurídica na ordem política", aproveitando um pretexto sem fundamento real e instaurando um processo político degradante, acompanhado de punição penal. Isso sempre inflamado por apoio midiático e apelo classista. Para o autor, é a posse de Lula o momento imediato da assunção dessa linha ativista.

Santos vai elencando alguns passos da AP 470 ao mesmo tempo em que menciona a queda da desigualdade de renda, a criação de programas de habitações populares e a sequência de ganhos reais dos salários mínimos, entre outras conquistas. Era difícil à sensibilidade conservadora digerir tamanha intervenção na desigual pirâmide social brasileira. Gradativamente, o quadro foi mudando. O otimismo do crédito foi sucedido pela ansiedade do endividamento. A crise global foi equivocadamente interpretada pelo empresariado e pela grande classe média como efeito de políticas sociais somadas à incompetência do partido dirigente - e, claro, à corrupção. A AP 470 era o instrumento legitimador desse discurso. É importante ter claro que o problema dessa ação penal não consistiu apenas na prisão de certas figuras populares. Para além dessas condenações, a AP 470 fraudou a lógica política institucional, lançando os seguintes fundamentos, que no limite podem servir a novos pretextos para potenciais 
golpes parlamentares:

a) Sequestro do poder constituinte do povo, manifesto expressamente na afirmação do ex-ministro Joaquim Barbosa de que a Constituição é aquilo que o Supremo Tribunal Federal diz que ela é — o que é, em essência, equivocado, uma vez que não é a autoridade judicial que cria a constitucionalidade, e sim o contrário. O poder constitucional é intransferível, e é o povo, em Assembleia Constituinte, que diz o que ela é;

b) Disjunção epistemológica entre ser inocente e não ser culpado, conforme se vê nas decisões que eram tomadas antes do julgamento. O caráter kafkiano do julgamento se percebe por momentos em que, como descreve o autor, a única prova que o acusado poderia dar de inocência seria demonstrar que não conhecia certo aspecto da operação fraudulenta da qual só os participantes tinham conhecimento. Se somente participando dela se poderia afirmar inocente, o acusado era, desde o princípio, já culpado;

c) Imputação de possibilidade objetiva e causalidade adequada, que Santos sintetiza na extraordinária justificativa da ministra Rosa Weber a seu voto: condeno porque a bibliografia me autoriza. Isso acrescido de outro voto, em que a mesma ministra afirma que quanto mais elevada a posição de alguém na cadeia de comando, mais facilitada lhe é a cautela de apagar pistas. Foi assim que, "ao final de dias de debates sem a apresentação de qualquer prova da participação de José Dirceu no crime que lhe era atribuído, o enunciado de teoria jurídica de Rosa Weber vestia lindamente seu voto pela condenação. E assim foi." (Santos, 2017, p. 175)

\subsection{Luís Felipe Miguel: resgatar a participação}

É um paradoxo o ponto de partida de Luís Felipe Miguel (2017) em seu artigo sobre democracia participativa: ele começa lembrando o entusiasmo de muitos acadêmicos e ativistas que enalteciam a criação dos espaços participativos, com ênfase nas políticas de orçamento participativo (e já de imediato recordamos a leitura de Santos e Avritzer, de quinze anos antes). Por outro lado, Miguel levanta as mudanças que aconteceram no sentido do que se chama "participação política", chegando a qualificar de ingênuas algumas percepções anteriores.

Essa abordagem inicial de Miguel não ocorre por acaso. Ele considera que isso reduziu bastante a capacidade de interpretação crítica dos limites das democracias liberais e do impacto das diferentes formas de desigualdade de recursos nas possibilidades de intervenção pública. Isso porque os espaços que no passado geravam empolgadas análises pouco foram capazes de pôr em questão a reprodução dos padrões de dominação que ele diz estarem entranhados nas estruturas políticas ainda vigentes.

O que Miguel (2017) observa, na verdade, é um movimento em dois passos, que irão ser as linhas mestras de sua análise:

1) A redução da participação à esfera do Estado;

2) A diluição da fronteira entre participação e representação.

Antes de entrar no exame desses dois aspectos, ele empreende uma leitura da chamada compreensão clássica da democracia participativa, elaborada por Carole Pateman (1992). No olhar dessa pensadora, a participação política se dá para além da esfera do Estado. Sua aposta é de que a participação direta nos locais da vida cotidiana supriria o estímulo à qualificação política, uma vez que, participando da autogestão, um sujeito se diferenciaria de um trabalhador assalariado comum por precisar estar mais bem informado e compreender mais do mundo para contribuir de forma efetiva no processo de tomada coletiva de 
decisões, uma vez que elas afetam sua vida. Um efeito disso é a efetividade da fiscalização dos atos dos representantes políticos, isto é, a efetividade da accountability, para a qual o cidadão seria treinado, ao passo que nas democracias liberais têm aplicação precária.

Mas nem tudo são flores nessa linha participacionista. Embora os defensores dessa tese afirmem que seu mérito reside no "potencial" de estímulo à participação das pessoas, o fato é que, no conjunto, elas são, na maior parte do tempo, apáticas, desinformadas e desinteressadas. Isso pôde ser comprovado em estudos de campo. Relações interpessoais, poder deliberativo e a ignorância que essa linha "patemaniana" tem de instituições como a família são alguns dos problemas dessa vertente.

A partir dos anos 1980, com o declínio dessa corrente, haverá uma ascensão de uma outra, de caráter deliberacionista. Aqui, o autor destaca a sofisticação teórica, mas de imediato coloca limitação no seu potencial crítico, uma vez que apresenta menor sensibilidade para o efeito político das assimetrias sociais. De qualquer modo, essa vertente não se expandiu pela via teórica, mas pela aplicação prática, em especial nas políticas de orçamento participativo. Mas Miguel não se empolga com a medida:

Fica evidente que a participação do OP está muito mais ligada ao sentido fraco do que ao sentido forte da palavra. Embora ocorram variações de local para local e ao longo do tempo, ele é tipicamente uma estrutura delegativa piramidal. Todos os moradores têm a possibilidade de participar das discussões em assembleias de base (embora apenas uma minoria o faça), que culminam com a eleição de uma lista de prioridades e de um número de delegados. Muitas vezes, as prioridades ainda são transformadas pela aplicação de pesos predeterminados por especialistas da prefeitura. E os delegados eleitos se encontram e escolhem outros, num processo que termina por produzir um "conselho", com poderes para negociar, amalgamar e substituir as prioridades votadas. É o conselho que, no final das contas, produz a proposta orçamentária - na verdade, um adendo a uma proposta orçamentária, já que o grosso dos recursos públicos pertence a rubricas fixas e não passa pelo conselho de representantes da base. (Miguel, 2017, pp. 95-96)

Uma crítica adicional de Miguel consiste no fato de que a participação popular não vai além da escolha de delegados. Não se diferencia da participação eleitoral, portanto. Assim, "as experiências de OP promovem uma duplicação de instâncias representativas, sem a transferência de poder decisório final [grifos do autor] para os cidadãos comuns" (Miguel, 2017, p. 96). Apesar de tudo, ele pensa que o OP pode proporcionar espaços de capacitação política mais densos do que o processo eleitoral. Assim, o entendimento do valor da OP pode variar. De qualquer modo, seus limites são claros: sua política dá-se no Estado, dentro dele. A vida dentro das empresas não é atingida. Miguel se ressente do fato de que as propostas originais de democracia participativa iam até as relações de produção, não deixando o mercado fora de sua alçada.

Com o maior ceticismo que experiências como o OP passam a ter, na primeira década deste Século XXI, a literatura especializada se guiará numa outra direção. Passa a haver, em grande medida impulsionadas pela ascensão do PT ao governo federal, uma virada em favor de uma "representação política de resultados", que, no entender do autor, "não apenas desloca o conjunto de parâmetros que permite avaliar a qualidade do vínculo representativo nos novos espaços de interlocução, como também anula a preocupação com a educação política, central nas visões participacionistas anteriores” (Miguel, 2017, p. 101). Ainda assim, os resultados positivos alcançados não se sustentaram no tempo, sendo incapazes de alterar o paradigma de precariedade cidadã, tal como entende Espírito Santo (2021), o que, também segundo ela, explica em boa medida o caráter instável da democracia brasileira.

O deslocamento em questão passa a ser da relação representante-base para representante-representante. A figura do representante autoinstituído, muitas vezes assumindo tais posições pela visibilidade que têm na sociedade civil, frequentemente não tem qualquer interlocução válida com aqueles pelos quais diz falar. Esse tipo de advocacy, diz Miguel, pode ser meritório e legítimo, porém não é uma forma de representação democrática.

O articulista lembra que, quando fala em representação democrática ou em participação direta, não está iludidamente se referindo à democracia direta tal como no modelo grego. Ele é inviável, e isso não se questiona. O foco reside na necessidade 
de interlocução e compromisso de representatividade às preferências dos representados, isto é, "mecanismos de autorização e accountability menos formalizados, à margem dos procedimentos eleitorais, mas que podem surgir nas relações cotidianas de lideranças com suas bases" (Miguel, 2017, p. 113).

Todo o esforço, portanto, deve ser no sentido de fugir de um entendimento paternalista de participação, que estabelece que as pessoas são incapazes de atuar politicamente. $\mathrm{O}$ ideal de igualdade é coextensivo à democracia. Se um é abandonado, o outro também o é.

\subsection{Vladimir Safatle e o esgotamento do lulismo, ou Para além da melancolia}

Em Só Mais um Esforço, o filósofo Vladimir Safatle (2017) arrisca uma reflexão em certa medida radical sobre a "decomposição de um país" e os caminhos para a esquerda brasileira. Seu elemento principal de questionamento é a lógica da conciliação de classes, que marcou a experiência petista na presidência da República. O componente que representa essa experiência é o chamado lulismo, fenômeno que o autor acredita estar encerrado, e com ele encerrado o ciclo populista que o PT representou. E é justamente o momento em que ele discute o esgotamento do lulismo que nos interessa como ponto de partida da obra.

O lulismo não acaba com o golpe; quando Dilma adentra no segundo turno, ele já era passado. O que Safatle levanta como paradoxo central é que os operadores do desmonte final do lulismo não foram sempre opositores do governo; em sentido contrário, eles foram por muito tempo parte do que o autor chama, num primeiro momento, de "consórcio governista petista". E complementa:

Ou seja, os atores do pós-golpe parlamentar de 2016 não eram outros senão os próprios negociadores do consórcio governista nos governos Lula-Dilma, agora associados aos oposicionistas derrotados nas urnas, nas últimas quatro eleições presidenciais. Diante de uma revolta popular contra o poder, eles simplesmente usaram a tática milenar de sacrificar o sócio mais novo do consórcio do poder (a saber, o PT) para que pudessem continuar gerindo o Estado como nunca deixaram de fazer. (Safatle, 2017, p. 80)

Por essa sentença, pode-se deduzir algo que é muito caro à compreensão das disputas políticas modernas, que é a questão do poder. Quando fala em "consórcio do poder", o filósofo deixa claro que o poder de Estado não é uno, coerente, mas sim diverso, contraditório. Sustentado por um consórcio, esse poder contempla diferentes correntes políticas, tanto mais quanto mais heterogênea for a sua base social. O PT, no fim das contas, nunca foi o detentor do poder. No entanto, não se pode dizer que não foi parte dele. Durante treze anos, ocupou a presidência e postos estratégicos do Estado, exercendo forte influência sobre outros. A coalizão que montou, contudo, se compunha em grande parte de representantes das frações que tradicionalmente sempre foram parte desse consórcio. Rangel (2021) destaca que a luta de classes, no Brasil, acontece substancialmente dentro do pacto de poder, o que explicaria as nossas "transições pelo alto". Nesse pacto de poder, o PT, sendo o sócio mais novo, era também o mais frágil. Caindo o PT, o pacto manteve-se intacto.

A atuação do PT como força moderada não aconteceu por acaso. Se na primeira década de sua história, esse partido apresentava teses radicais para a economia e a sociedade brasileiras, num segundo momento eles passaram a dirigir governos locais por meio dos quais atenuou esse radicalismo, chegando à presidência com um viés mais próximo da social democracia europeia do que da esquerda personalista e carismática que logrou sucesso eleitoral em outros países vizinhos na América do Sul.

Tendo utilizado o Estado como indutor de processos de ascensão social, os bancos públicos de investimentos como os grandes financiadores do capitalismo nacional e montado uma coalizão bastante diversificada, o lulismo pensava ter consolidado um projeto duradouro de poder. Safatle, contudo, considera que aí residia uma grande ilusão. Ao deixar de preconizar a 
transformação da institucionalidade, o lulismo permitiu que se mantivessem conservados os núcleos de poder que não apenas paralisavam eventualmente o governo, mas preservavam as estruturas oligárquicas presentes, por exemplo, no Congresso Nacional e no Poder Judiciário. Além disso, o mercado ditava forte tom no processo político. Lula inflou o governo, transformando-o em palco fundamental das disputas sociais, como entre monetaristas e desenvolvimentistas que se digladiavam no Ministério da Fazenda e no Banco Central, ou entre ecologistas e o agronegócio, cujos embates aconteciam nos ministérios da Agricultura e do Meio Ambiente. Mantendo coesa a sua base social, a popularidade do presidente alcançou níveis estratosféricos, a ponto de a oposição a Lula em 2010, quando fez sua sucessora, ser mínima.

Dilma Rousseff, contudo, não conseguiu realizar as expectativas do desenvolvimento social produzidas por Lula. Essa ressaca provocou o que Safatle coloca como "frustração relativa", conceito de Tocqueville que procura explicar o fato de as revoltas e revoluções muitas vezes não advirem dos desfavorecidos, mas por grupos que ganharam — e que esperavam ganhar mais. Bem, parece ter sido isso o que aconteceu nos emblemáticos movimentos de Junho de 2013, ocasião que o autor considera uma chance que a esquerda não aproveitou para se reorientar, para romper com o núcleo governista. Não o fazendo, os conflitos que cindiram o movimento, disputando-o pela direita e pela esquerda (e que perdurou por alguns meses e anos), terminou com o setor conservador tomando definitivamente a frente em março de 2015. A partir daí, as manifestações tomam claro caráter antipetista.

Vale destacar que as tantas incompreensões a respeito desses movimentos também são lembradas por Safatle. A inoperância dos intelectuais, a paralisia do governo, a incapacidade de se criar atores políticos e organizações que se adequassem ao perfil desses protestos, entre outros fenômenos, fizeram com que a esquerda fosse paulatinamente sendo escanteada no processo. Iludida pela premissa liberal de que política caminha com gestão, ela se esqueceu de um ensinamento fundamental, a saber, o de que "a política é indissociável da capacidade de incorporar forças anti-institucionais", como diz o próprio Safatle (2017, p. 115). Restringindo-se aos limites do Estado de Direito, a esquerda governista agia de forma autoritária. Fazendo-o, perdia as condições de dialogar com os manifestantes.

Porém, a derrota política é, também, ou especialmente, o que se faz dela. Assim, tendo a psicanálise como base, Safatle vai refletir sobre o comportamento melancólico que se apoderou de sujeitos de forças políticas. A melancolia, segundo Freud (2012), se refere ao amor por objetos perdidos. Tendo se identificado com tais objetos, o Eu passa a ser sombreado por eles, e se paralisa quando estão em falta. O efeito disso é, por um lado, fixação, mas também pode ser ressentimento. Essa posição melancólica impede que o luto se complete. Reforça a sensação de impotência, trava a imaginação e leva esses sujeitos a desconfiarem de sua própria força. Passam a se tornar dependentes de amparo. Só que não há política na demanda de amparo, e sim a reiteração de estruturas de poder que aproveitam essas circunstâncias para se perpetuarem.

Por isso, há de se desconfiar dessa desconfiança em relação à nossa força e começar por nos perguntarmos se o medo da perda não seria exatamente aquilo que deveria ser perdido (grifo nosso). Há de se recusar toda forma de amparo e de cuidado, afirmar nosso desamparo relativo a toda colonização. Um desamparo que é condição inicial da verdadeira criação, pois é afirmação de um desabamento que nos joga para fora das formas de vida que se impuseram a nós de maneira hegemônica. (Safatle, 2017, p. 123)

Com essas reflexões, o autor procura lembrar à esquerda que ela não é o que parece ser, e assim fazer emergir um novo espírito. Essa ilusão de impotência que a acomete é o cenário perfeito para governos neoliberais aplicarem suas propostas de "autonomia" das instâncias econômicas, para assim distanciá-las da influência da política, mostrando-se agora como sempre foram: "um modo de gestão social, modo de organização disciplinar das minhas vontades, do meu tempo, das minhas atividades e cuja força não vem do que ela seja capaz de realizar, mas do medo que é capaz de gerir" (Safatle, 2017, p. 124). É por isso que o discurso econômico é, em sua análise, o principal gestor de nossa melancolia social.

O filósofo caminha para suas conclusões defendendo uma reinvenção política. Sua proposta é de uma radicalização da 
democracia. Além de Legislativo e Executivo, uma verdadeira democracia precisa de assembleias populares com poderes de ratificar leis, orçamentos, reformas constitucionais, situações de emergência, guerras e assim por diante. O povo deve ter, afinal, estruturas que o permitam se defender de quem lhe procura usurpar o poder. Isso é o que Safatle chama de "grau zero de representação", com o Estado deixando de ser espaço de deliberações políticas e se tornando mero espaço de implementação de deliberações advindas de seu exterior. Se dizem que essa medida geraria o caos, ele diz, em resposta, que a representação é um arcaísmo político. Se defendem a consolidação de mecanismos de controle, ele diz, em contraposição, que o que devemos criar é uma sociedade descontrolada. Ele se aproxima dos pensamentos radicais de Zizek (2019), uma de suas principais referências. Para o esloveno, não é de esperança que a esquerda precisa, mas sim o contrário: extrair coragem da desesperança, tirando forças da percepção de que parece não haver caminho a seguir.

Safatle não está preocupado com as perguntas. A clássica questão leniniana que sempre reaparece nos tempos difíceis, “que fazer?”, não é, para o filósofo, uma questão a ser respondida. Ele está mais interessado no que vem da imaginação do que no que vem das pressões que recaem sobre nós. Reafirma que a política é a crença improvável e aparentemente louca de que podemos ser outros. Será que viria daí a jogada de efeito que poderia tirar a democracia brasileira da sinuca de bico em que se encontra?

\section{Considerações Finais}

Dizia o escritor Nelson Rodrigues (2012), um dos maiores cronistas de costumes da vida brasileira, que muitas vezes é a falta de caráter que decide uma partida. Mas essa sua opinião não se restringia ao esporte (em especial o futebol, pelo qual era apaixonado), de modo que ele fez questão de acrescentar: não se faz, também, literatura e política com bons sentimentos, afinal.

Esse olhar, recheado de uma dura franqueza, parece também uma crônica dos tempos contemporâneos de nossa vida política. Particularmente nos últimos anos, com o completo desequilíbrio do exercício de poder, com Judiciário e Legislativo interferindo para além de qualquer escrúpulo na vida política, e a ascensão de políticas de governo que deverão intensificar a uberização nas relações de trabalho, a precarização dos serviços públicos e pauperização da vida social, não surpreende pensar que são qualquer coisa, menos bons pensamentos, que estão dominando a cena na política nacional. Mas isso não pode nos impedir de avaliá-la com rigor, sem que no entanto recaiamos num extremismo de sinal oposto.

Essas leituras sobre a democracia brasileira que ora trouxemos, feitas por alguns dos mais importantes estudiosos de nosso país nas últimas décadas, trazem diferentes enfoques do problema em tela, e é menos importante pensar nas suas divergências que nas contribuições de cada um. Tendo recortes temporais e fundamentações teóricas diferentes, compará-los fortuitamente seria um mero exercício de elucubração que nos levaria do nada a lugar nenhum. As ciências sociais, também elas um alvo desses tempos obscuros, precisam ir além disso.

Há um consenso, no entanto, que é o de que a democracia liberal chegou a um grau de esgotamento que somente uma leitura muito instrumental dela poderia considerar que vivemos em tempos normais. Definitivamente, nosso ordenamento jurídico (e político) se sustenta sobre areia movediça, e até pensar se de fato as próximas eleições virão a acontecer é algo que costumeiramente nos gera dúvidas. O definhamento da política é reflexo imediato da degradação econômica, e efeito concreto do golpe de 2016.

Assim, não parece forçado observar as linhas gerais do atual desmantelamento de políticas sociais e da destituição de um governo de inclinação popular via golpe e recordar o que discutimos lá em Coutinho (1979). O crescimento da participação coletiva na vida política, seja pelas conferências sobre diversos temas, pela crescente presença dos movimentos sociais nas discussões públicas e pela importância que obtiveram os programas sociais nas mesas políticas, foram caminhos que talvez abrissem margem para, no longo prazo, a constituição de um sujeito político coletivo, capaz de lograr hegemonia suficiente para influir nos destinos dos rumos institucionais, operando medidas de transformação dessas estruturas — senão pelo PT, por outras 
organizações que viessem a acumular força nesse processo. Parece-nos que se abre um flanco aqui onde somente novos estudos muito mais aprofundados — que necessariamente têm produção demorada, de modo que nem sempre são publicados no calor dos acontecimentos - devem avaliar adequadamente em que medida as instituições conseguiram resistir a esses episódios traumáticos.

De qualquer maneira, a leitura do golpe parlamentar feita por Santos (2019) já é um esforço nessa direção, e o que vemos nela não é a negação da tese de Coutinho, mas quem sabe a sua confirmação. Ainda que Santos não se ampare num referencial marcadamente marxista, é evidente o caráter de classe em sua leitura do golpe, desconstruindo a mistificação da pauta anticorrupção e colocando as questões sociais como alvo central do governo biônico de Michel Temer, sequenciado por um governo populista de direita, o de Jair Bolsonaro, que está fora de nosso escopo de análise, mas que reforça grande parte das críticas aqui levantadas - diga-se de passagem, apesar de aqui abordarmos o referido mandatário como um populista, concordamos com Missiatto (2021) que ele vai além disso, sendo expressão do que contemporaneamente se entende por necropolítica, tal como fica evidenciado por seus necrodiscursos. Contudo, o que nos resta é compreender as vicissitudes de nossa democracia para saber em que medida a autonomia relativa do Estado permite a um projeto popular se alçar ao poder e ali alcançar estabilidade suficiente para aplicar medidas que de fato se proponham a reformular a estrutura historicamente desigual do país.

Com efeito, é natural que o momento histórico condicione as formulações que se constroem sobre os temas sociais e políticos. A mostra mais clara disso que tivemos foi na leitura de Santos e Avritzer (2002), feita num momento em que as medidas participativas, sendo inovadoras e bem aprovadas, geravam entusiasmo e expectativa de amplificação. Naquele momento, a atuação no interior do Estado, a exemplo do que afirma Miguel (2017), era o que dava a tônica. Sendo um passo atrás em relação ao que propunha a visão que este autor chamou de "patemaniana", ainda assim reforçavam o crédito das figuras políticas que o promoviam, de modo geral ligadas ao PT.

A ascensão do PT ao Governo Federal, porém, foi exatamente o que este mesmo autor observou como obstáculo ao crescimento dessas medidas. Tendo sido fundado como um partido classista de pautas radicais — inclusive proclamando em seus fóruns a defesa de um "socialismo petista", termo, porém, nunca preciso - , Safatle (2017) lembra que o PT moderou bastante a sua linha nos anos 1990, chegando em 2003, primeiro ano de seu governo, já bem situado dentro da ordem burocrática do Estado e completamente desinteressado na promoção de mudanças. A aplicação de medidas liberais (ampliação do superávit primário, manutenção do tripé macroeconômico, reforma da previdência, etc.) demonstraram que sua presença no governo não viria gerar abalos estruturais no edifício do capitalismo brasileiro, mas sim humanizá-lo, a partir de políticas de transferências de renda (via programas sociais, promoção de crédito e elevação do salário mínimo) e de crescimento dos investimentos em áreas sociais. Essa linha não se contrapunha, em seus fundamentos, à anterior, preconizada pelo governo neoliberal de FHC. No entanto, no quadro de um país estruturalmente desigual, não é exagero dizer que elas tiveram caráter histórico.

Promovendo o revés democrático e nas políticas de promoção da igualdade, um governo biônico geriu o país por dois anos, chegando a aprovar uma emenda constitucional que limitou o teto de gastos públicos, o que pode levar à paralisia não só do Estado mas de toda a economia no espaço de alguns anos, se outras alternativas não forem pensadas, e foi sucedido por um governo populista de direita, com discurso não raro extremista e que constantemente flerta com o golpismo, como se vê no desprezo às vias institucionais e na inflamação de discursos maniqueístas. O caráter de classe do nosso Estado (e, portanto, da democracia formal) tem sido evidente no reforço estatal de certas frentes de atuação (especialmente via aparelhos de repressão e órgãos de controle) e no desmantelamento das políticas de transferência de renda (reforçando o poder econômico das frações de classe dominante).

Em adição a isso, os agentes que promoveram o golpe em 2016 foram, em boa medida, secundarizados. Outras corporações (isto é, outras frações de classe) (re)apareceram na cena política, sendo a mais proeminente (e perigosa) delas os 
militares. O governo de Bolsonaro tem mais militares em seu ministério que mesmo os governos da própria ditadura regida pelas Forças Armadas. Isso altera o equilíbrio de forças do país, uma vez que os militares, que muito intervieram no processo político e constituinte na fase de redemocratização, conforme lembra Spinelli (2014, p. 72), atuam sempre "impondo seus interesses próprios ou afirmando aspectos específicos de sua ideologia social conservadora". Além deles, se destacam também os representantes de igrejas neopentecostais, o mais arcaico segmento do ramo latifundiário e outras alas ultraliberais da economia. Se há um consórcio de poder e nele os mesmos agentes continuam exercendo o comando em última instância, a autonomia relativa do Estado agora pode dar margem a reformulações estruturais à direita do espectro - com imposições de pautas morais reforçada por entidades conservadoras em detrimento de medidas fundamentadas em estatísticas e dados científicos e intensificação das formas de exploração de mais-valia relativa (e absoluta) —, e não mais à esquerda como se pretendia. Estamos mesmo em xeque. Qual a próxima jogada nesse quadro? O caminho passa por defender essa institucionalidade da iminência de novos ataques, que no limite podem levar a um novo regime de exceção? Ou pela radicalização propalada por Safatle, isto é, pela construção de vias anti-institucionais? Entre outras saídas possíveis, essas duas parecem as mais proeminentes. Mas quando o conflito se torna democracia versus ditadura, não nos resta muitas possibilidades de escolha, e nisso temos a fundamentação enfática de Coutinho (1979), o único dentre os autores analisados que defendeu a via democrática ainda no quadro de um regime autoritário.

Entretanto, se não nos empolgamos com um certo voluntarismo radical de Safatle (2017), pelo menos concordamos num ponto: as respostas não são urgentes. É mais importante voltarmos a nos perguntar, e repensarmos nosso próprio comportamento. Nesse sentido, esse dilema democrático brasileiro ainda deverá ser muitas vezes elencado como objeto de estudos. Por mais que o populismo de direita seja um fenômeno passageiro, a instabilidade de nossa democracia exige que a estudemos melhor, seja por meio de seu aparato institucional, as normas jurídicas sobre as quais se amparam ou os atores que a compõem e protagonizam seus episódios mais enfáticos. No fim das contas, os agentes que promoveram diversos avanços na vida brasileira há poucos anos continuam aí - e ao falar nisso não nos referimos a apenas um partido, mas a vários que foram partícipes do processo, bem como outros movimentos, outros personagens, e o mais importante: o conjunto dos segmentos populares que deram base para isso. A reversão do quadro, portanto, é possível. Continuamos em xeque é verdade; mas o mate (ainda) não foi dado.

\section{Referências}

Bobbio, N. (1979). Marxismo e Estado. Ed. Graal.

Coutinho, C. N. (1979). A democracia como valor universal. Encontros com a Civilização Brasileira. 9 (1), 33-49.

Costa, D. M. D. (2009). 20 Anos de Orçamento Participativo: análise das experiências nos Municípios Brasileiros. Anais do Encontro da Associação Nacional dos Programas de Pós-Graduação em Administração, São Paulo, Brasil, 33.

Dahl, R. (2001). Sobre a democracia. Editora da Universidade de Brasília.

Freud, S. Luto e melancolia. In: Freud, S. (1996). Obras psicológicas completas de Sigmund Freud. 19. Ed. Imago.

Habermas, J. (1996). Entre fatos e normas. Tempo Brasileiro.

Maciel, D. (2012). De Sarney a Collor: reformas políticas, democratização e crise. (1985-1990). Ed. Alameda.

Miguel, L. F. (2017). Resgatar a participação: Democracia participativa e representação política no debate contemporâneo. Lua Nova, São Paulo, 100, 83-118.

Minayo, M. C. dos S. (org.) n/a et al. (2016). Pesquisa social: teoria, método e criatividade. Vozes.

Missiatto, L. A. F. (2021). Necrodiscursos: Discursos articulados pelas políticas da morte. Research, Society and Development, 10(8), e14810817302. https://doi.org/10.33448/rsd-v10i8.17302

Pateman, C. (1992). Participação e teoria democrática. Paz e Terra.

Poulantzas, N. (2019). Poder político e classes sociais. Martins Fontes. 
Research, Society and Development, v. 10, n. 16, e257101623940, 2021

(CC BY 4.0) | ISSN 2525-3409 | DOI: http://dx.doi.org/10.33448/rsd-v10i16.23940

Rangel, I. (2021). Obras reunidas. (2) Contraponto Editora.

Ribeiro, Renato Janine. In: Geiselberger, H. (org.). (2019) A grande regressão. Ed. Estação Liberdade.

Rodrigues, N. (2012). Nelson Rodrigues por ele mesmo. Ed. Nova Fronteira.

Espirito Santo, G. O. M. do. (2021). A cidadania brasileira à luz dos valores neoconstitucionais: Uma análise da democracia participativa no Brasil do século XXI. Research, Society and Development, 10(7), e35810716789. https://doi.org/10.33448/rsd-v10i7.16789

Santos, B de S.; Avritzer, L. Para ampliar o cânone democrático. In: Santos, B. de S. (Org.). (2002). Democratizar a democracia: os caminhos da democracia participativa. Ed. Civilização Brasileira.

Santos, W. G. dos. (2007). A democracia impedida: o Brasil no século XXI. Editora FGV.

Safatle, V. (2007). Só mais um esforço. Editora Três Estrelas.

Schumpeter, J. (2017). Capitalismo, socialismo e democracia. Edunesp.

Spinelli, A. (2014) Mudança social e crise no capitalismo: Leituras sociológicas. Edufrn.

Zizek, S. (2019). A coragem da desesperança: crônica de um ano em que agimos perigosamente. Jorge Zahar Editor. 